\title{
Intensive English Program (IEP) Meningkatkan Penguasaan Vocabulary
}

\author{
Eva Sulistiana ${ }^{1^{*}}$, Wardatun Nadzifah ${ }^{2}$, Moh. Samsul Arifin ${ }^{3}$ \\ STIKes Hafshawaty Pesantren Zainul Hasan \\ ${ }^{* 1}$ evamawardi@gmail.com | 2wardah.def@gmail.com | 3 arifinsamsul1186@gmail.com
}

\begin{abstract}
Abstrak
Vocabulary merupakan salah satu komponen dalam penguasaan bahasa asing untuk mendukung mahasiswa dalam mempraktekan speaking dengan baik. Usaha untuk meningkatan vocabulary menjadi kendala bagi para mahasiswa yang belajar bahasa inggris sebagai bahasa asing. Peningkatan vocabulary bisa dilakukan menggunakan berbagai upaya. Salah satunya melalui program Intensive Bahasa Inggris. Program Intensive menfasilitasi para mahasiswa dengan jadwal yang intensive, materi dan praktik percakapan. Tujuan dari penelitian ini adalah untuk mengetahui pengaruh intensive English Program dalam meningkatan vocabulary pada mahasiswa Stikes Hafshwaty. Metode penelitian menggunakan pre-experimental dan desain one group pre and post test design. Populasi yang digunakan adalah mahasiswa Tingkat 1 Stikes Hafshawaty Pesantren Zainul Hasan sebanyak 106 mahasiswa. Teknik sampling menggunakan cluster sampling, diperoleh sampel 84 mahasiswa. Pengumpulan data menggunakan format penilaian dan wawancara serta dianalisis menggunakan paired t-test. Hasil penelitian menginformasikan bahwa nilai rata rata vocabulary sebelum treatment adalah 1.4881 dan sesudah treatment 2.2500 atau terjadi peningkatan sebesar 0.7619 kali. Berdasarkan uji statistik diperoleh $p$ $=0,000(<0,05)$ sehingga ada pengaruh yang signifikan antara Intensive English Program terhadap kemampuan berbicara bahasa Inggris.
\end{abstract}

Kata Kunci: program intensive Bahasa Inggris, penguasaan vocabulary

\section{Pendahuluan}

Di era globalisasi menguasai bahasa Inggris merupakan sebuah keharusan. Kemampuan berbahasa Inggris menjadi salah satu nilai tambah. Bahasa Inggris diajarkan mulai dari level Sekolah Dasar, Sekolah Menengah Pertama, Sekolah Menengah Atas hingga level Perguruan Tinggi. Demikian Juga mahasiswa Sekolah Tinggi Kesehatan yang notabene merupakan mahasiswa non-Bahasa Inggris. Paramedis seperti dokter, perawat, bidan dan tenaga kesehatan harus menguasai bahasa inggris sebagai bahasa International Karena banyaknya peralatan medis dalam bahasa Inggris pun cara pengoperasianya menggunakan bahasa Inggris. Itu merupakan salah satu bukti pentingnya penguasaan Bahasa Inggris. Mata kuliah bahasa Inggris menjadi salah satu mata kuliah wajib yang harus dipelajari. Sinaga (2010) Kemampuan Bahasa Inggris mampu menunjang dan kesuksesan dalam bidang akademik sekaligus memberikan extra skill yang akan menunjang karir di dunia kerja.

Dalam proses belajar bahasa Inggris, terdapat empat kemampuan penting yaitu kemampuan mendengarkan, berbicara, membaca dan menulis. Kemampuan mendengarkan dan membaca termasuk dalam kategori receptive skills (kemampuan menerima input), sedangkan berbicara dan menulis termasuk dalam productive skills (kemampuan menggunakan bahasa). 
Selain empat skill diatas, terdapat empat komponen pendukung dalam berbahasa Inggris yaitu pronunciation (pelafalan), vocabulary (kosa kata), dan grammar (struktur bahasa). Penguasaan empat komponen tersebut membantu tercapainya penguasaan bahasa Inggris yang optimal, disamping itu porsi praktek yang banyak dan pendidik yang professional juga merupakan factor penentu kebehasilan penguasaan bahasa inggris.

Salah satu indikator penguasaan bahasa Inggris adalah Vocabulary Seperti yang dinyatakan oleh Nunan (1991) bahwa kosakata merupakan hal yang penting agar dapat menggunakan bahasa kedua (second language). Kosakata membantu dalam mempelajari penggunaan struktur dan fungsi bahasa dalam berkomunikasi. Tarigan (1986) menyatakan bahawa kualitas berbahasa seseorang tergantung pada kualitas kosakata yang dimiliki. Banyaknya kosakata membantu ketrampilan berbahasa. Maka tidak dapat dipungkiri bahawa kosakata merupakan komponen penting dalam membentuk bahasa.

Kurangnya kosa kata mahasiswa mempengaruhi keterampilan lain dalam pembelajaran bahasa seperti keterampilan mendengarkan, berbicara, membaca dan menulis yang berarti pengetahuan kosa kata memainkan peran penting dalam pembelajaran bahasa. Telah diperhatikan bahwa peserta didik dengan pengetahuan kosa kata dalam jumlah besar dapat dengan mudah menguasai keterampilan lain dalam suatu bahasa dan memiliki. Muncie (2002) menyatakan bahwa pengetahuan kosa kata yang banyak membantu pemahaman membaca ,menulis yang baik serta membantu pemahaman tes bahasa secara keseluruhan. Muncie (2002) juga menyatakan bahwa peserta didik dengan pengetahuan kosa kata yang banyak membantu peserta didik untuk memiliki kinerja akademik yang lebih baik.

Dalam pengajaran kosakata terdapat beberapa langkah yang dapat diterapkan seperti yang dinyatakan oleh Lado (1979), langkah yang dapat diterapkan dalam pembelajaran kosakata yaitu: (1)mendengarkan (2) mengucapkan kata (3) memaknai kata (4) membuat ilustrasi dalam bentuk kalimat (5) melakukan latihan dalam pengekspresian makna (6) mengucapkan kata tersebut dengan suara keras dan (7) menulis kata kata tersebut. Sedangkan menurut Sitorus (1993) menyatakan bahwa katakata yang terdapat dalam kelompok, golongan-golongan, dan dalam suatu perangkatperangkat selalu lebih mudah untuk dipelajari. Lebih lanjut Sitorus (1993) mengungkapkan ada dua cara mempelajari kosakata dalam pengelompokan yaitukelompok kata yang mempunyai satu dasar umum dan kelompok kata yangmempunyai hubungan dalam pengertian.

Kosakata merupakan komponen pembentuk bahasa. Tujuan dari pembelajaran kosakata adalah untuk berkomunikasi. Kesulitan dalam penguasaan kosakata tidak hanya dialami oleh mahasiswa jurusan bahasa Inggris tetapi juga dialami oleh mahasiswa non bahasa Inggris. Hali ini disebabkan karena penguasaan kosakata seringkali dipelajari dengan cara menghafal, hal ini menjadi juga dirasakan oleh para mahasiswa, mereka beranggapan bahwa belajar kosakata haruslah dilakukan dengan cara menghafal. Lebih daripada itu penguasaan kosakata erat kaitannya dengan pembentukan kalimat. Pembelajaran kosakata akan lebih efektif jika digunakan dalam kontek kalimat langsung.

Kami melakukan preliminary study terhadap mahasiswa STIKES Hafshawaty di Tahun pertama kuliah, dari hasil tersebut didapat bahwa sebanyak $70 \%$ mahasiswa memiliki penguasaan kosakata bahasa Inggris yang masih rendah. Hasil wawancara menunjukkan bahwa kemampuan penguasaan kosakata mahasiswa masih rendah. Hal ini dikarenakan sebagian besar dari mahasiswa menggunakan metode menghafal. Sehingga kosakata yang sudah dihafalkan akan hilang karena tidak pernah di digunakan dalam percakapan. Hal lainnya adalah sebagai mahasiswa non bahasa Inggris mereka merasa bahwa porsi belajar bahasa 
Inggris sangatlah kurang sehingga mereka kesulitan dalam penguasaan bahasa Inggris khususnya penguasaan kosakata.

Diperlukan upaya dalam mengatasi permasalahan diatas. Salah satu upaya tersebut adalah melalui Intensive English Program. IEP adalah program pembelajaran bahasa Inggris dengan intensitas yang padat dalam waktu yang singkat. Sehingga English learners benar benar fokus untuk belajar.

Penelitian serupa yang pernah dilaksanakan oleh Reema Abouzeid (2018) dengan judul" The Effect of an Intensive English Program on the Vocabulary Size of Lebanese English Foreign Learners" IEP dalam konteks bahasa asing ini memiliki dampak positif pada kemahiran siswa dalam bahasa Inggris dan hasilnya memberikan dukungan untuk efektivitas program ini.

Dalam penelitian Jayakaran Mukundan, Elaheh Hamed Mahvelati \& Vahid Nimehchisalem (2012) yang berjudul "The Effect of an Intensive English Program on Malaysian Secondary School Students' Language Proficiency" menyatakan bahwa Program Intensif Satu Bulan dengan durasi 120 jam merupakan bukti bahwa manfaat nyata yang dapat dicapai dalam program intensif. Serta kolabarosai adalah penting demi suksesnya program Intensif bahasa Inggris.

\section{Metode Penelitian}

Penelitaian ini menggunakan penelitian pre-experimental dengan one group pre and post test design. Populasi yang digunakan adalah mahasiswa Tingkat 1 Stikes Hafshawaty Pesantren Zainul Hasan sebanyak 106 mahasiswa. Teknik sampling menggunakan cluster sampling, diperoleh sampel 84 mahasiswa. Pengumpulan data menggunakan format penilaian dan wawancara serta dianalisis menggunakan t-test dan paired t-test.

\section{Hasil Penelitian}

Penelitian ini menggunakan dua variable yakni, IEP dan penguasaan kosakata. Dari hasil penelitian didapatkan informasi bahwa penguasaan kosakata Bahasa Inggris Mahasiswa Stikes Hafshawaty mengalami perubahan hal ini dapat dilihat pada table pre dan post test selama mengikuti Intensive English program (IEP).

Tabel 1. Vocabulary pre-test

\begin{tabular}{llrrrr}
\hline & & Frequency & Percent & Valid Percent & Cumulative Percent \\
\hline Valid & Kurang & 56 & 66.7 & 66.7 & 66.7 \\
& Cukup & 16 & 19.0 & 19.0 & 85.7 \\
& Baik & 11 & 13.1 & 13.1 & 98.8 \\
& Sangat Baik & 1 & 1.2 & 1.2 & 100.0 \\
\cline { 2 - 5 } & Total & 100.0 & 100.0 & \\
\hline
\end{tabular}

Tabel 1 menunjukkan category kemampuan vocabulary mahasiswa pada saat pre-test atau sebelum penerapan Intensive English Program (IEP). Mahasiswa yang berada pada kategori sangat baik hanya 1 mahasiswa atau 1\%, dalam kategori baik ada 11 mahasiswa atau $13 \%$, kategori cukup berjumlah 16 mahasiswa atau $19 \%$ sedangkan 56 atau 66,6\% mahasiswa masuk dalam kategori kurang. Hal ini menunjukkan bahwa kemampuan vocabulary sebagian besar mahasiswa masih rendah atau berada pada kategori kurang. 
Tabel 2. Vocabulary post test

\begin{tabular}{llrrrr}
\hline & Frequency & Percent & Valid Percent Cumulative Percent \\
\hline Valid & Kurang & 2 & 2.4 & 2.4 & 2.4 \\
& Cukup & 60 & 71.4 & 71.4 & 73.8 \\
Baik & 21 & 25.0 & 25.0 & 98.8 \\
Sangat Baik & 1 & 1.2 & 1.2 & 100.0 \\
\cline { 2 - 5 } & Total & 100.0 & 100.0 & \\
\hline
\end{tabular}

Tabel 2 menunjukan bahwa nilai pos test vocabulary mahasiswa setelah pelaksanaan Intensive English Program (IEP) pada kategori sangat baik adalah 1mahasiswa atau $1 \%$, kategori baik sebanyak 21atau $25 \%$, kategori cukup 60 mahasiswa atau 71\% dan dalam kategori kurang berjumlah 2 mahasiswa atau 2,3\%. Hal ini meginformasikan bahwa penguasaan vocabulary mahasiswa setelah pelaksanaan Intensive English Program (IEP) berda pada kategori cukup.

Tabel 3. Statistik Sampel Berpasangan

\begin{tabular}{lrrr}
\hline & & $\begin{array}{r}\text { Vocabulary } \\
\text { Pretest }\end{array}$ & $\begin{array}{r}\text { Vocabulary } \\
\text { Posttest }\end{array}$ \\
\hline $\mathrm{N}$ & Valid & 84 & 84 \\
& Missing & 0 & 0 \\
Mean & 1.4881 & 2.2500 \\
Median & 1.0000 & 2.0000 \\
Mode & 1.00 & 2.00 \\
\hline Minimum & 1.00 & 2.00 \\
\hline Maximum & 4.00 & 4.00 \\
\hline
\end{tabular}

Dari Tabel 3 diperoleh informasi bahwa nilai rata rata (mean) mahasiswa Stikes Hafshawaty dalam penguasaan kosakata sebelum mengikuti Intensive English program adalah 1.4881 dan mengalami perubahan setelah mengikuti IEP menjadi 2.2500 atau meningkat sebanyak 0,7619 .

\section{Pembahasan}

Peningkatan Jumlah mahasiswa yang mempunyai kemampuan vocabulary dalam kategori cukup 16 mahasiwa atau 19\% meningkat setelah pelaksanaan Intensive English Program (IEP) menjadi 60 mahasiswa atau $71 \%$. Hal ini terjadi karena durasi proses belajar dalam IEP adalah dua kali lipat dari durasi waktu yang biasa mereka peroleh di kelas ketika belajar bahasa inggris. IEP berlangsung dengan durasi $50 \times 2$ menit dalam satu pertemuan, kegiatan IEP dilaksanakan 2 kali tatap muka dalam satu minggu dan berlangsung selama kurun waktu 8 minggu. Total pelaksanan IEP adalah 16 pertemuan. Selain itu Intensive English Program (IEP) menerapkan pembelajaran yang melibatkan 4 Skill yaitu speaking, listening, grammar dan Vocabulary. Materi disesuaikan dengan kebutuhan mahasiswa yaitu English for Spesific Purpose, materi bahasa Inggris untuk mahasiswa Sekolah Tinggi Ilmu Kesehatan.

Rata rata kemampuan vocabulary nahasiswa juga meningkat setelah pelaksanaan Intensive English program. Peningkatan nilai rata rata kemampuan vocabulary dari 1.4881 menjadi 2.2500 atau meningkat sebanyak 0,7619. Hal ini merupakan dampak positif dari pembiasaan pembiasaan yang diterapkan dalam Intensive English Program (IEP). Kegiatan seperti drilling dan conversation dalam porsi yang banyak mampu meningkatkan penguasaan kosakata mahasiswa. Dengam mempraktikan conversation berarti menggunakan koskata kata kedalam 
konteks kalimat langsung. Hal inilah yang secara tidak langsung dapat memperkaya kosakata bahasa inggris mahasiswa.

\section{Kesimpulan}

Peningkatan penguasaan kosakata setelah mengikuti Intensive English program merupakan indikasi bahwa IEP mampu meningkatkan penguasaan kosakata bahasa Inggris mahasiswa Stikes Hafshawaty Pesantren Zainul Hasan. Dapat disimpulkan bahwa Intensive English program (IEP) merupakan slah satu alternative yang bisa digunakan dalam upaya peningkatan penguasaan kosakata bahasa Inggris.

Perlu kiranya untuk mengembangkan program peningkatan kemampuan bahasa Inggris, khususnya penguasaan kosakata sehingga mampu meningkatkan kemampuan berbahasa inggris mahasiswa. Pembelajaran kosakata erat hubunganya dengan kegiatan berbicara, sebaiknya para pengajar bahasa inggris memperbanyak kegiatan praktek berbicara dalam proses belajar kosakata bahasa Inggris. Upaya lain yang bisa dilakukan pembiasaan menghafal kosakata dengan metode yang menyenangkan. Sehingga para mahasiswa tidak mempunyai pemahaman bahwa belajar kosakata merupakan hal yang sulit.

\section{Ucapan Terimakasih}

Ucapan terima kasih disampaikan kepada Kementerian Riset, Teknologi, dan Pendidikan Tinggi (Kemenristekdikti) Republik Indonesia atas dukungan dana dalam penelitian ini.

\section{Referensi}

Abouzeid, R. (2018). The Effect of an Intensive English Program on the Vocabulary Size of Lebanese English Foreign Learners. International Journal of English Linguistics, 8(6).

Sinaga, F. (2010). Peranan Bahasa Inggris Dalam Era Globalisasi. http://kursusinggris.wordpress.com, diakses tanggal 20 September 2019

Lado, R. (1979). Language teaching. A scientific approach. Bombay-New Delhi: Tata McGrawHill Publshing Co.LTD.

Muncie, J. (2002). Process writing and vocabulary development: comparing Lexical Frequency Profiles across drafts. System, 30. 225-235

Mukundan, J., Mahvelati, E. H., \& Nimehchisalem, V. (2012). The effect of an intensive English program on Malaysian secondary school students' language proficiency. English

Language Teaching, 5(11), 1-7. https://doi.org/10.5539/elt.v5n11p1

Nunan, D. (1991). Language teaching methodology: A textbook for teachers. Sydney: Prentice Hall International (UK) Ltd.

Sitorus, R. H. (1993). Cara mudah belajar bahasa Inggris: English vocabulary. Bandung: CV. Pionir Jaya.

Tarigan, H. G. (1986). Pengajaran kosakata. Bandung: Penerbit Angkasa 